\title{
THE EFFECT OF TRAINING AND INFORMATION TECHNOLOGY ON EMPLOYEE WORK INNOVATION AND ITS IMPACT ON ACEH REGIONAL SECRETARIAT PERFORMANCE
}

\author{
*T. Efdhan, Mahdani and Sulaiman \\ Management Department, Universitas Syiah Kuala, Indonesia \\ http://doi.org/10.35409/IJBMER.2021.3264
}

\begin{abstract}
This study aims to determine the effect of training and information technology on the organizational performance through the work innovation behavior. The study population was all employees of the Aceh Regional Secretariat, Indonesia, totaling 609 employees in 2019. The number of sample used in this study was 7 times the number of indicators in the research variables as much as $7 \times 18=126$ employees. The result shows that Training significantly affects work innovation behavior of employees, Information technology significantly affects work innovation behavior, Training significantly affects the performance of the Aceh Regional Secretariat, Information technology significantly affects the performance of the Aceh Regional Secretariat, work innovation behavior significantly affects the performance of the Aceh Regional Secretariat, work innovation behavior does not play a significant role in mediating the effect of training on the performance of the Aceh Regional Secretariat, and work innovation behavior does not play a significant role in mediating the effect of information technology on the performance of the Aceh Regional Secretariat. This evidence reveals that the model for improving the performance of the Aceh Regional Secretariat, the variable of training, information technology, and work innovation behavior plays a very important role, and the work innovation behavior does not act as a mediator in this research model so that all exogenous variables can directly affect the performance variable. This tested model serves as a finding that can contribute to academics and further researchers are advised to develop this model by adding other variables such as talent management and human capital management.
\end{abstract}

Keyword: Training, Information Technology, Work Innovation Behavior, Secretariat Performance.

\section{INTRODUCTION}

In Indonesia, the change in the political direction of the country after the implementation of regional autonomy was marked by the presence of Law Number 23 of 2014 concerning Regional Government and the implementation of bureaucratic reforms that have made the role of Regional Heads in Aceh Province, one of the provinces in the country, increasingly occupying and holding a fairly large and significant position of control today. Law Number 11 of 2006 concerning Aceh Governance has also expanded the duties of Regional Heads as regional government administrators, regional development administrators, and community administrators. 


\section{International Journal of Business Management and Economic Review}

Vol. 4, No. 03; 2021

ISSN: 2581-4664

This condition has contributed to the complexity of the tasks of the Aceh Regional Secretariat, which is directly under its authority.

The Aceh Regional Secretariat as the main organization of the regional government in Aceh Province, Indonesia, has been dedicated to contributing significantly to regional development and the quality of the social life of the community through the realization of an orderly, efficient, and effective regional government administration system in all Aceh Province. In the middle of these demands, the quality performance of the Regional Secretariat is increasingly expected so that all development targets and problems faced by the Regional Head can be resolved. As a result, the Aceh Regional Secretariat has been able to optimally achieve strategic targets every year as stated in the Government Agencies Performance Accountability Report (LAKIP). This performance achievement cannot be separated from the various steps taken. Various activities and work behaviors are shown by the State Civil Apparatus at work will also contribute to the achievement of the Aceh Regional Secretariat's performance, including work innovation behavior.

The behavior of innovation encourages the State Civil Apparatus at the Aceh Regional Secretariat to abandon the old, inefficient and bureaucratic ways and strive to be able to think creatively in applying new knowledge and ways of working. Employees who have work innovation behavior are employees who work with other unexpected approaches and often do not follow procedures that are considered inefficient, solve problems in different and dynamic ways even though there are rules or leadership power that regulates and directs them, dare to do tasks and be able to generate new ideas including irrelevant, unreasonable and unexciting ideas (Sutrisno, 2019). The work innovation behavior can achieve improvements in several activities that can improve personal and organizational performance (Jong \& Hartog, 2008).

The implementation of bureaucratic reform has given birth to several concepts and ideas in the current State Civil Apparatus (ASN) development, especially the improvement of employee competency and work discipline, but this trend has not yet been able to produce better work innovation behavior of the employees. The problem is that various forms of work carried out by employees today must always be directed by their superiors, without any good ideas for acting on their own. The low level of work innovation behavior of employees is also indicated by the lack of employees to find out about new work methods, techniques, or instruments. The low quality and quantity of the education and training programs organized by the local government and the lack of the ability of the State Civil Apparatus in absorbing information technology are some of the factors that influence the low innovation behavior of the State Civil Apparatus at the Aceh Regional Secretariat.

Training programs are a solution in balancing the needs of agencies on the one side and the needs of employees on the other, so that job demands can be faced by employees dynamically. Training programs can also introduce new ways of working that can create innovative ideas at work. Although the employee development system at the Aceh Regional Secretariat currently has many employees who have completed undergraduate and postgraduate education, this increase in educational levels has not been able to guarantee that employees can work innovatively. So that a quality and effective training program from the government is needed. However, the fact is that the training and education programs run by the government are often not planned well. In fact, many of the training programs carried out were government projects at the end of the fiscal year, without focusing on efforts to improve the quality of human 


\section{International Journal of Business Management and Economic Review}

Vol. 4, No. 03; 2021

ISSN: 2581-4664

resources so that in the end the training program did not have a significant impact on employee work innovation behavior.

Then information technology is also one of the factors that influence the work innovation behavior of employees at the Aceh Regional Secretariat. The pressure of modernization on public organizations currently makes the Aceh Regional Secretariat need to be equipped with modern work facilities including information technology. The information technology currently used by employees at the Aceh Regional Secretariat is a number of computer hardware and software connected to the internet network, has functioned to collect and store data on various agency activities. Computer devices have also processed thousands and millions of data into information that can be used in decision-making by all parties. With the current application of information technology resulted in employee lists, employee records, and other internal archive systems have been computerized effectively without having to go through a long and complicated bureaucracy. Ideally, the presence of information technology at the Aceh Regional Secretariat has been able to play a role in increasing the work activities of employees who are more creative and innovative and then have an impact on achieving the performance targets of the Aceh Regional Secretariat.

\section{LITERATURE REVIEW}

\section{The Effect of Training on Work innovation Behavior}

Work innovation behavior refers to the introduction of new and useful ideas (Jong \& Hartog, 2010). Bright ideas will be born if employees are always proactive in seeking new knowledge and experiences, sharing information, engaging in discussions, seeking criticism and feedback (Kassim, Jailani, Hairuddin, \& Zamzuri, 2012). Training is one of the factors that will accommodate all these needs. Then Hind (2008) in (Halawi \& Haydar, 2018) evaluates the relationship between knowledge management including training programs with creativity and innovation. The education and training program has a positive, direct and significant effect on creativity and innovation. Training has a positive and significant relationship to work innovation behavior. (Halawi \& Haydar, 2018).

\section{The Effect of Information Technology on Work innovation Behavior}

Information technology has been shown to positively influence organizational innovation through increasing the role of employees in the technology sector. The occurrence of an information exchange process between organizations and an organizational learning process has become a concept that underlies innovation in organizations (Kmieciak, Michna, \& Meczynska, 2012). Information and communication technology, play a fundamental role in building the basis for the adoption and implementation of knowledge innovation (Peñalba, Guzmán, \& Mojica, 2015). Information technology has had a dramatic impact on the reengineering of individual roles. Information technology can increase work innovation in organizations (Karadal \& Saygin, 2011).

\section{The Effect of Training on Organizational Performance}

Training refers to the acquisition of new skills, knowledge, and information that are directly required for performance. Organizations that develop good training designs according to the needs always get good results (Partlow, 1996). Effective training design considers learning 


\section{International Journal of Business Management and Economic Review}

Vol. 4, No. 03; 2021

ISSN: 2581-4664

concepts and different approaches to training play a very important role in employee and organizational performance (Tsai \& Lin, 2017). Learning through training is a key factor in improving employee performance, also affecting organizational performance (Harrison, 2000) in (Samwel, 2018).

\section{The Effect of Information Technology on Organizational Performance}

Information technology can drive better company performance. Information technology has the ability to create new resources, either by distributing or combining several other resources, in other words, with information technology capabilities, companies have a strategy to obtain various benefits. By developing the company's information technology capabilities, it can create superior value and can improve organizational performance (Jean, Sinkovics, \& Kim, 2008).

\section{The Effect Of Work innovation Behavior on Organizational Performance}

Innovation is where organizations adopt or develop ideas that diagnose, observe deficiencies, or prevent environmental problems (Doran \& Ryan, 2014). Organizations that have greater innovation will achieve a better response from their environment, find it easier to improve organizational performance capabilities (Moorman, Deshpandé, \& Zaltman, 1993) in (Zhang, Khan, Lee, \& Salik, 2019). Innovation has a direct impact on organizational performance (Zhang et al., 2019).

\section{The Effect of Training on Performance Through Work innovation Behavior}

Training is designed to improve skills and better work behavior including innovative behavior. Meanwhile, innovation in organizations is something that needs to be there to make the organization better in achieving its goals and objectives effectively and efficiently (Kumaat \& Dotulong, 2015). Ongoing training guarantees access to cutting-edge knowledge development and increases the tendency to innovate and increase progress in various fields within the company (Bauernschuster, Falck, \& Heblich, 2009) in (Dostie, 2017). Training has a positive and statistically significant impact on innovation and development in companies (Bauernschuster et al., 2009).

\section{The Effect of Information Systems on Performance through Work innovation Behavior}

The concept related to the use of IT involves developing new ideas or new ways to expand or find new ways to achieve the goals of the organization. The use of systems is important for organizational innovation and business performance (Min \& Fei, 2008).

\section{Theoretical Framework}

Based on the previous description, the research conceptual framework can be described as shown in Figure 1 below. 
Vol. 4, No. 03; 2021

ISSN: 2581-4664

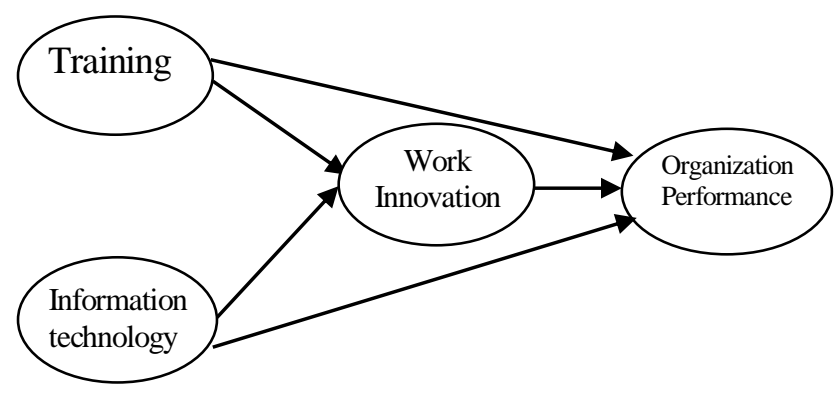

Figure 1. Theoretical Framework

\section{Hypothesis}

H1 : training significantly affects the work innovation behavior of employees at the Aceh Regional Secretariat.

H2 : information technology significantly affects the work innovation behavior of employees at the Aceh Regional Secretariat.

$\mathrm{H} 3$ : training significantly affects the performance of the Aceh Regional Secretariat.

H4 : information technology significantly affects the performance of the Aceh Regional Secretariat.

H5 : work innovation behavior significantly affects the performance of the Aceh Regional Secretariat.

H6 : work innovation behavior plays a significant role in mediating the effect of training on the performance of the Aceh Regional Secretariat.

H6 : work innovation behavior plays a significant role in mediating the effect of information technology on the performance of the Aceh Regional Secretariat.

\section{METHOD}

\section{Population and Sample}

The study population was all employees of the Aceh Regional Secretariat, totaling 609 employees in 2019. The number of sample used in this study was adjusted to the needs of the Structural Equation Model (SEM) analysis, which was at least 5 times the number of indicators (Ferdinand, 2014). However, the Maximum Likelihood Estimation (MLE) technique required a minimum sample range of 100-200 respondents. Based on this format, the sample size in this study was set at 7 times the number of indicators in the research variable as much as $7 \times 18=126$ employees.

\section{Operational Variable}


International Journal of Business Management and Economic Review

Vol. 4, No. 03; 2021

ISSN: 2581-4664

Table 1. Operational Variable

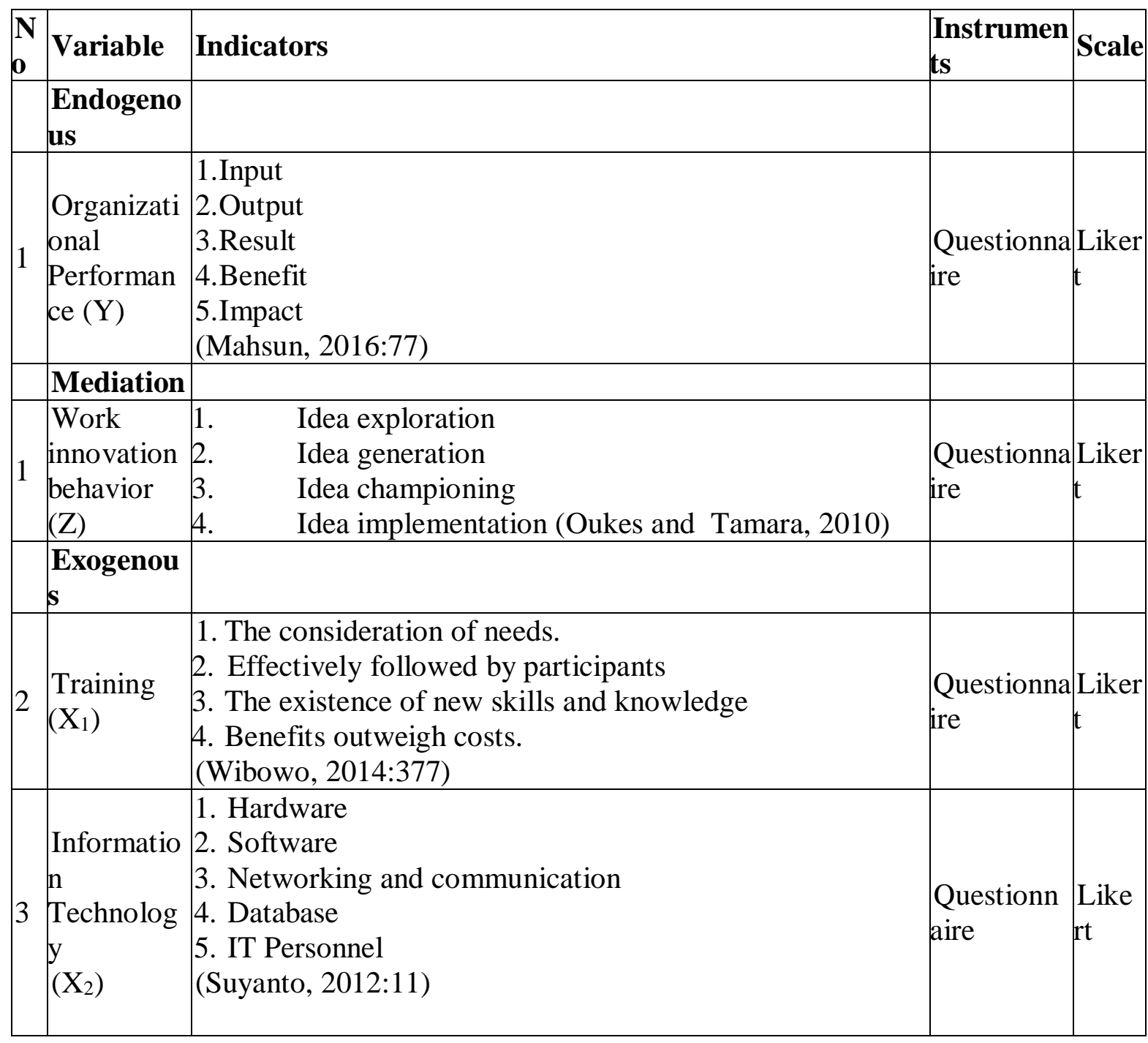

\section{Data Analysis Tools}

To test the effect of training, information technology on the performance of the Aceh Regional Secretariat which was mediated by work innovation behavior, Structural Equation Modeling (SEM) analysis was used.

\section{RESULT}

\section{Measurement Model}

The measurement model treats all exogenous and endogenous latent variables into one model so that it can be seen whether each indicator can play a role in explaining the construct of each variable. The contribution of the CFA value of each indicator is said to be valid if the value is $>0.50$. 
Vol. 4, No. 03; 2021

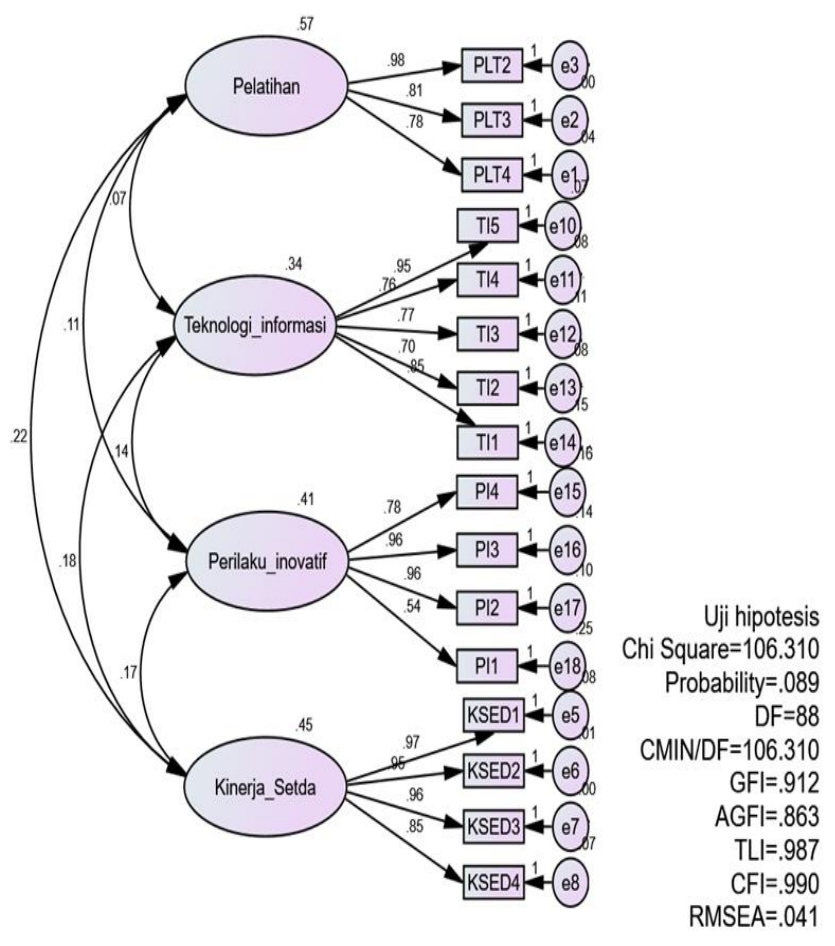

Figure 2. Measurement Model

Measurement model of 4 (four) research constructs variables latent which formed or described of 16 indicators were all declared valid because the overall loading value was above 0.5 and the overall regression weight significance value was below the 0.05 limit. More clearly the values of the loading factors can be explained in the table.

\section{Table 2 Loading Factors}

\begin{tabular}{|l|l|l|}
\hline Indicators $\quad$ Variables & $\begin{array}{l}\text { Estim } \\
\text { ate }\end{array}$ & \\
\hline PLT4 <-- Training & 0.781 & 0.00 \\
PLT3 <-- Training & 0.813 & 0.00 \\
PLT2 <-- Training & 0.980 & 0.00 \\
KSED2 <-- Regional & 0.947 & 0.00 \\
& Secretariat_Performance & \\
KSED3 <-- Regional & 0.961 & 0.00 \\
& Secretariat_Performance & \\
KSED4 <-- Regional & 0.845 & 0.00 \\
TI4 $\quad$ Secretariat_Performance & 0.758 & 0.00 \\
\hline
\end{tabular}


Vol. 4, No. 03; 2021

ISSN: 2581-4664

\begin{tabular}{|c|c|c|c|}
\hline Indicat & Variables & $\begin{array}{l}\text { Estim } \\
\text { ate }\end{array}$ & \\
\hline TI3 & $<-$ <- Information_technology & 0.768 & 0.00 \\
\hline & $<-$ Information_technology & 0.699 & 0.00 \\
\hline & <-- Innovative_behaviours & 0.785 & 0.00 \\
\hline & <-- Innovative_behaviours & 0.960 & 0.00 \\
\hline & <-- Innovative_behaviours & 0.960 & 0.00 \\
\hline & <-- Innovative_behaviours & 0.542 & 0.00 \\
\hline $\begin{array}{l}\text { KSED } \\
1\end{array}$ & $<-\begin{array}{l}\text { Regional } \\
\text { Secretariat_Performance }\end{array}$ & 0.970 & 0.00 \\
\hline TI5 & $<-$ Information_technology & 0.950 & 0.00 \\
\hline TI1 & $<-$ Information_technology & 0.848 & 0.00 \\
\hline
\end{tabular}

The measurement model also requires the fulfillment of a fit analysis model which can be proven as follows:

Table 3. The goodness of Fit Criteria

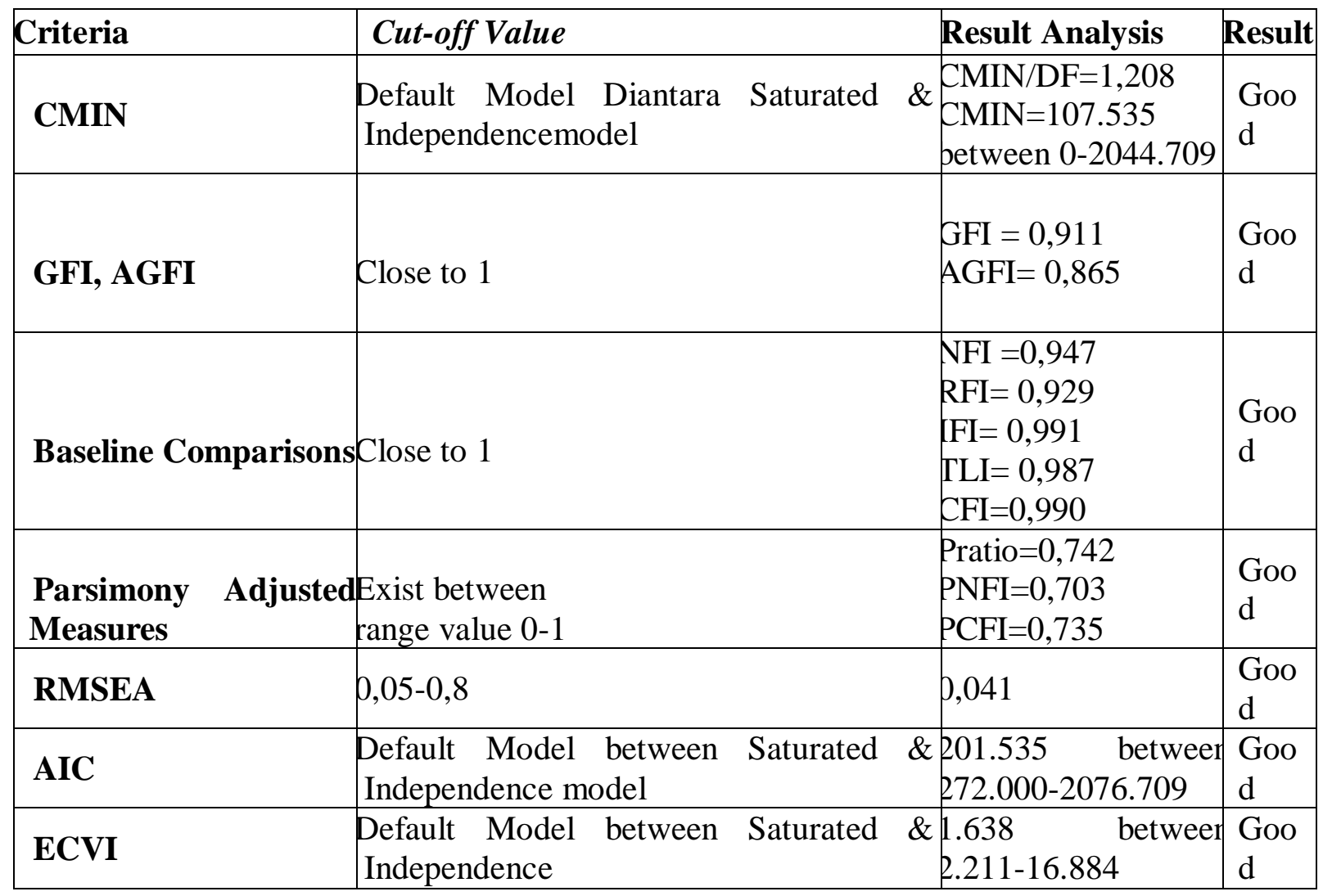

Information of model eligibility examining in the table above proved that all testing criteria have 
International Journal of Business Management and Economic Review

Vol. 4, No. 03; 2021

ISSN: 2581-4664

been met, the endogenous model variables that were built were fit and could meet the requirements for further analysis.

\section{Structural Model}

The structural model analysis explained the existence of a relationship between constructs that had a causal relationship (cause-effect) between latent or exogenous variables and endogenous variables. The structural analysis model can be explained as follows:

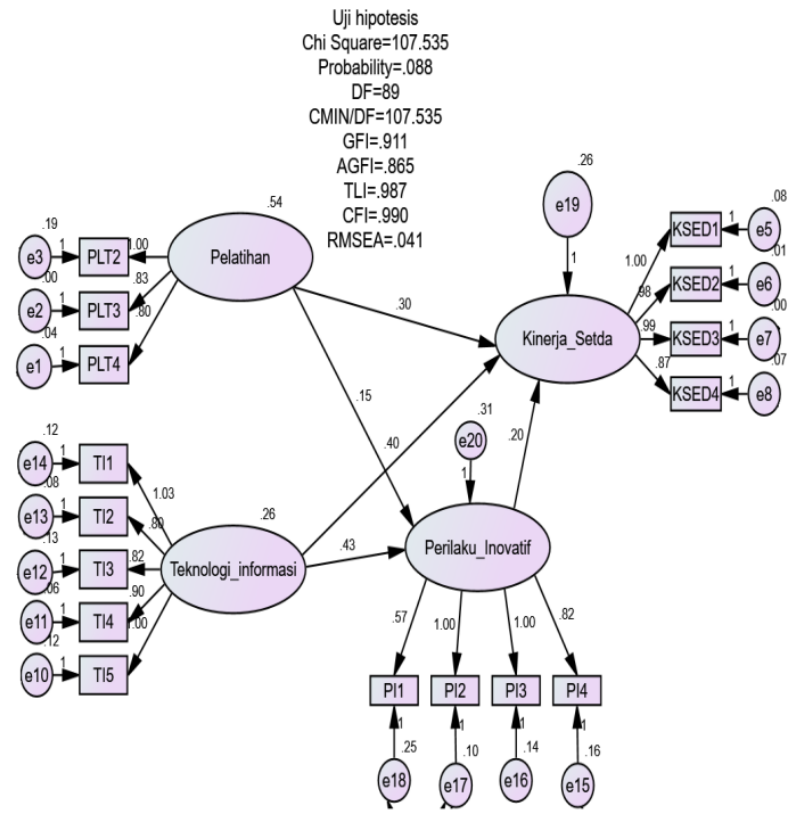

Figure 3. Structure Model

Direct Effect

Table 4. Estimate Regression Weight of Direct Effect.

\begin{tabular}{|c|c|c|c|c|c|c|}
\hline & & \multicolumn{2}{|c|}{ Estimate } & S.E. & \multicolumn{2}{|l|}{ C.R. } \\
\hline $\begin{array}{l}\text { Innovative } \\
\text { Behaviour }\end{array}$ & $\begin{array}{l}<-\quad \text { Information_technol } \\
\text { ogy }\end{array}$ & 0.426 & ). 112 & & 3.808 & $* *$ \\
\hline $\begin{array}{l}\text { Innovative } \\
\text { Behaviour }\end{array}$ & $<-\quad$ Training & 0.155 & 1.074 & & 2.096 & .036 \\
\hline $\begin{array}{l}\text { Regional } \\
\text { Secretariat_Perform } \\
\text { ance }\end{array}$ & $\begin{array}{l}<-\quad \text { Information_technol } \\
\text { ogy }\end{array}$ & 1.402 & I.107 & & 3.758 & $* *$ \\
\hline $\begin{array}{l}\text { Regional } \\
\text { Secretariat_Perform }\end{array}$ & $\begin{array}{l}<-\quad \text { Innovative_ } \\
\text { Behaviour }\end{array}$ & 0.203 & 1.089 & & 2.275 & .023 \\
\hline
\end{tabular}




\section{International Journal of Business Management and Economic Review}

Vol. 4, No. 03; 2021

ISSN: 2581-4664

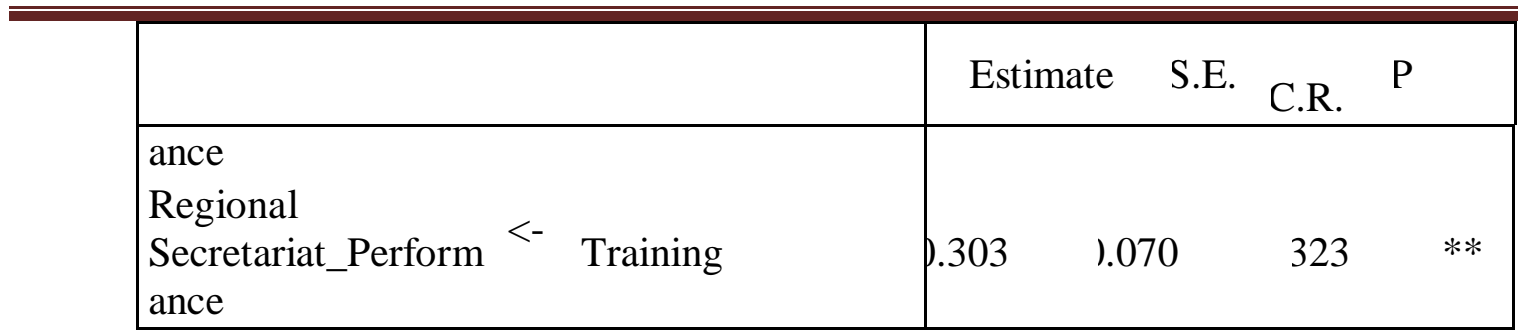

Table 5. Standardized Regression Weights

\begin{tabular}{|ll|l|}
\hline & & Estimate \\
\hline Innovative Behaviour & <-- Information_technology & .360 \\
Innovative Behaviour & <-- Training & .188 \\
Regional & <- Information_technology & .326 \\
$\begin{array}{l}\text { Secretariat_Performance } \\
\text { Regional }\end{array}$ & & \\
$\begin{array}{l}\text { Secretariat_Performance } \\
\text { Regional }\end{array}$ & <-- Innovative Behaviour \\
Secretariat_Performance & <-- Training & .194 \\
\hline
\end{tabular}

H1 : The effect of training on work innovation behavior

The training was a variable that played a positive role in improving employee work innovation behavior at the Aceh Regional Secretariat with a coefficient value of 0.188 , meaning that if the training program increases by 1 unit, the employee work innovation behavior at the Aceh Regional Secretariat will also increase by 0.188 units. The effect of training on work innovation behavior was significant with a probability value of 0.036 or less than 0.05 . This effect was also strengthened by the calculated C.R value of 2.096, or greater than the standard C.R value of 1.96 .

H2: The effect of information technology on work innovation behavior

Information technology was a variable that played a positive role in improving employee work innovation behavior at the Aceh Regional Secretariat with a coefficient value of 0.360 , meaning that if information technology increases by 1 unit, the employee work innovation behavior at the Aceh Regional Secretariat will also increase by 0.360 units. The effect of information technology on work innovation behavior was significant with a probability value of 0.000 or less than 0.05 . This effect was also strengthened by the calculated C.R value of 3.808 , or greater than the standard C.R value of 1.96 .

H3 : The Effect of training on the Aceh Regional Secretariat Performance

The training was a variable that played a positive role in improving the performance of the Aceh Regional Secretariat with a coefficient value of 0.353, meaning that if the training program increases by 1 unit, the performance of the Aceh Regional Secretariat will also increase by 0.353 units. The effect of training on the performance of the Aceh Regional Secretariat was significant 


\section{International Journal of Business Management and Economic Review}

Vol. 4, No. 03; 2021

ISSN: 2581-4664

with a probability value of 0.000 or less than 0.05 . This effect was also strengthened by the calculated C.R value of 4.323, or greater than the standard C.R value of 1.96.

H4 : The effect of information technology on the Aceh Regional Secretariat performance

Information technology was a variable that played a positive role in improving the performance of the Aceh Regional Secretariat with a coefficient value of 0.326, meaning that if the information technology program increases by 1 unit, the performance of the Aceh Regional Secretariat will also increase by 0.326 units. The effect of information technology on the performance of the Aceh Regional Secretariat is significant with a probability value of 0.000 or less than 0.05 . This effect was also strengthened by the calculated C.R value of 3.758, or greater than the standard C.R value of 1.96 .

H5 : The effect of work innovation behavior on the Aceh Regional Secretariat performance

Employee work innovation behavior at the Aceh Regional Secretariat had a positive role in improving the performance of the Aceh Regional Secretariat with a coefficient value of 0.194, meaning that if the work innovation behavior increases by 1 unit, the Aceh Regional Secretariat performance will also increase by 0.194 units. The influence of work innovation behavior on the performance of the Aceh Regional Secretariat was significant with a significant probability value of 0.023 or less than 0.05 . This influence was also strengthened by the calculated C.R value of 2.275 , or greater than the standard C.R value of 1.96 .

Indirect Effect

Table 6 The Estimation of Indirect Effect

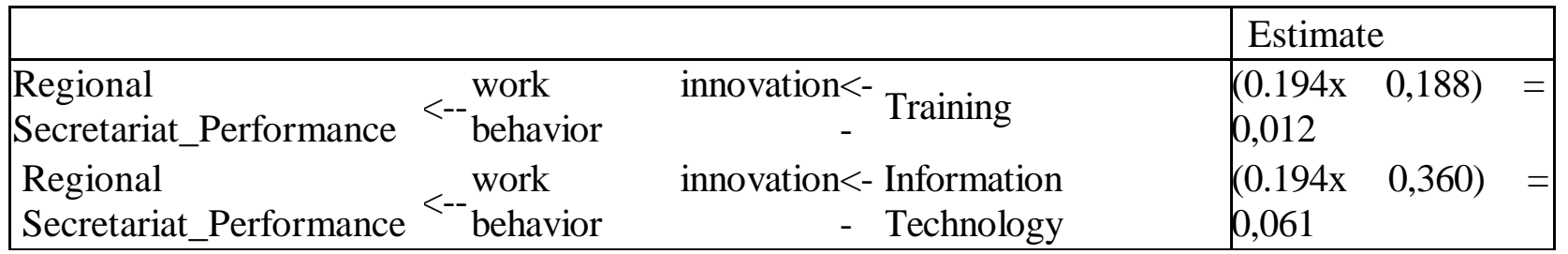

H6 : The effect of training on the Aceh Regional Secretariat performance through work innovation behavior

The effect of training on the performance of the Aceh Regional Secretariat through work innovation behavior obtained a mediation value of 0.012 , which meant that work innovation behavior could play a role in increasing the effect of training on the performance of the Aceh Regional Secretariat of 0.012. Hypothesis testing can be done using the Sobel test as follows:

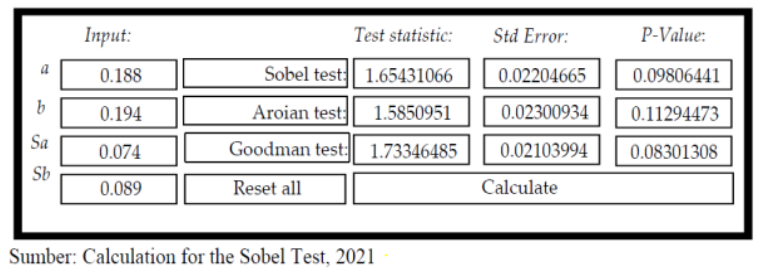

Figure 4 : Sobel Test for H6 


\section{International Journal of Business Management and Economic Review}

Vol. 4, No. 03; 2021

ISSN: 2581-4664

Based on the Sobel test estimation results as in the picture above, it could be explained that training did not significantly affect the performance of the Aceh Regional Secretariat through work innovation behavior with a P-Value of 0.098 or greater than the significant value limit of 0.05 . This effect was also strengthened by the statistical test value of 1.654 , or less than the standard value of C.R, which was 1.96 .

H7: The effect of information technology on the Aceh Regional Secretariat performance through work innovation behavior.

The influence of information technology on the performance of the Aceh Regional Secretariat through work innovation behavior obtained a mediation value of 0.061 , meaning that work innovation behavior was able to play a role in increasing the influence of information technology on the performance of the Aceh Regional Secretariat of 0.061. Hypothesis testing can be done using the Sobel test as follows:

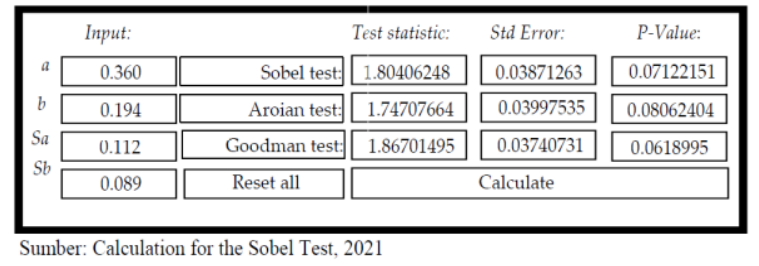

Figure 5 : Sobel Test for $\mathrm{H} 7$

Based on the Sobel test estimation results as in the picture above, it could be explained that information technology did not have a significant effect on the performance of the Aceh Regional Secretariat through work innovation behavior with a P-value of 0.07122 or greater than the significant value limit of 0.05 . This effect was also strengthened by the Sobel Test statistical test value of 1.8041 or less than the standard C.R value of 1.96 .

\section{CONCLUSION}

The result shows that Training significantly affects work innovation behavior of employees, Information technology significantly affects work innovation behavior, Training significantly affects the performance of the Aceh Regional Secretariat, Information technology significantly affects the performance of the Aceh Regional Secretariat, Work innovation behavior significantly affects the performance of the Aceh Regional Secretariat, Work innovation behavior does not play a significant role in mediating the effect of training on the performance of the Aceh Regional Secretariat, and Work innovation behavior does not play a significant role in mediating the effect of information technology on the performance of the Aceh Regional Secretariat. This evidence reveals that the model for improving the performance of the Aceh Regional Secretariat, the variable of training, information technology, and work innovation behavior plays a very important role, so these variables really need special attention. And the test results also reveal that work innovation behavior does not act as a mediator in this research model so that all exogenous variables can directly affect the performance variable. This tested model serves as a finding that can contribute to academics and further researchers are advised to 


\section{International Journal of Business Management and Economic Review}

Vol. 4, No. 03; 2021

ISSN: 2581-4664

develop this model by adding other variables such as talent management and human capital management.

There are still several advantages and disadvantages of the variables and research indicators in this research. Some recommendations are mapped. For the Aceh Regional Secretariat, this organization can open opportunities for employees to be able to implement work innovations. Also, the leader can implement training programs effectively for employees so that training can provide new insights, skills, and knowledge on the job. The organization also needs to expand the use of software that helps expedite administrative activities. For the employees, they must develop a learning process and skills so that they can create good work innovation behavior.

\section{REFERENCES}

Bauernschuster, S., Falck, O., \& Heblich, S. (2009). Training and Innovation. Journal of Human Capital, 3(4), 323-353. https://doi.org/http://dx.doi.org/10.1086/653713

Doran, J., \& Ryan, G. (2014). Eco-Innovation - does additional engagement lead to additional rewards? International Journal of Social Economics, 41(11), 1110-1130. https://doi.org/https://doi.org/10.1108/IJSE-07-2013-0169

Dostie, B. (2017). The Impact of Training on Innovation. ILR Review, 71(1), 64-87. https://doi.org/https://doi.org/10.1177/0019793917701116

Ferdinand, A. (2014). Structural Equation Modeling dalam Penelitian Manajemen (5th ed.). Semarang: Badan Penerbit Universitas Diponegoro.

Halawi, A., \& Haydar, N. (2018). Effects of Training on Employee Performance: A Case Study of Bonjus and Khatib \& Alami Companies. International Humanities Studies, 5(2), 24-45.

Harrison, R. (2000). Learning, knowledge productivity and strategic progress. International Journal of Training and Development, 4(4), 244-258. https://doi.org/https://doi.org/10.1111/1468-2419.00111

Jean, R. "Bryan," Sinkovics, R. R., \& Kim, D. (2008). Information technology and organizational performance within international business to business relationships: A review and an integrated conceptual framework. International Marketing Review, 25(5), 563-583. https://doi.org/https://doi.org/10.1108/02651330810904099

Jong, J. de, \& Hartog, D. den. (2010). Measuring Innovative Work Behavior. Creativity and Innovation Management, 19(1), 23-36. https://doi.org/10.1111/j.1467-8691.2010.00547.x

Jong, J. de, \& Hartog, D. N. Den. (2008). Innovative Work Behaviour: Measurement and Validation. Creativity and Innovation Management, 19(1), 24-36. https://doi.org/10.1111/j.14678691.2010.00547.x

Karadal, H., \& Saygın, M. (2011). The Effect of Information Technology on Innovation Abilities: A Research on SMEs. International Conference on Eurasian Economies, 396-399. https://doi.org/10.36880/C02.00309

Kassim, E. S., Jailani, S. F. A. K., Hairuddin, H., \& Zamzuri, N. H. (2012). Information system acceptance and user satisfaction: The mediating role of trust. International Conference on Asia Pacific Business Innovation and Technology Management, 412-418. 


\section{International Journal of Business Management and Economic Review}

Vol. 4, No. 03; 2021

ISSN: 2581-4664

https://doi.org/10.1016/j.sbspro.2012.09.1205

Kmieciak, R., Michna, A., \& Meczynska, A. (2012). Innovativeness, empowerment and IT capability: evidence from SMEs. Industrial Management \& Data Systems, 112(5), 707-728. https://doi.org/https://doi.org/10.1108/02635571211232280

Kumaat, R. J., \& Dotulong, L. O. . (2015). Pengaruh Pendidikan, Pelatihan, Dan Inovasi Terhadap Kinerja Pegawai Badan Pelaksana Penyuluhan Dan Ketahanan Pangan Kota Manado. Jurnal EMBA, 3(3), 331-340. https://doi.org/https://doi.org/10.35794/emba.v3i3.9393

Min, Q., \& Fei, X. (2008). The Impact of Information System Usage on Performance: Based on the innovation perspective. International Conference on Information Management, Innovation Management and Industrial Engineering, 137-140. https://doi.org/10.1109/ICIII.2008.76

Moorman, C., Deshpandé, R., \& Zaltman, G. (1993). Factors Affecting Trust in Market Research Relationships. Journal of Marketing, 57(1), 81-101. Retrieved from http://www.jstor.org/stable/1252059

Partlow, C. G. (1996). Human-Resources Practices of TQM Hotels. Cornell Hospitality Quarterly, 37(5), 67-77. https://doi.org/https://doi.org/10.1177/001088049603700526

Peñalba, J. E. M., Guzmán, G. M., \& Mojica, E. G. de. (2015). The Effect of Information and Communication Technology in Innovation Level: The Panama SMEs Case. Journal of Business \& Economic Policy, 2(2), 124-131.

Samwel, J. O. (2018). Impact of Employee Training on Organizational Performance - Case Study of Drilling Companies in Geita, Shinyanga and Mara Regions in Tanzania. International Journal of Managerial Studies and Research, 6(1), 36-41. https://doi.org/http://dx.doi.org/10.20431/2349-0349.0601005

Sutrisno, E. (2019). Budaya Organisasi. Jakarta: Prenada Media.

Tsai, M.-C., \& Lin, J.-C. (2017). The Influence Of Inertia On Repurchase Intention Of Hypermarket Customers. International Journal of Economic and Research, 8(2), 41-67.

Zhang, Y., Khan, U., Lee, S., \& Salik, M. (2019). The Influence of Management Innovation and Technological Innovation on Organization Performance. A Mediating Role of Sustainability. Sustainability, 11, 1-21. https://doi.org/https://doi.org/10.3390/su11020495 